\title{
幾何学的不連続を持つ磁気絶縁電力伝送線の実効インピーダンス
}

\author{
学生員 平岡一毅 (東工大) \\ 非会員 中島充夫 (東工大) \\ 非会員 志甫 諒 (日本原子力研究所) \\ 正員堀岡一彦 (東工大)
}

\section{Effective Impedance of Magnetically Insulated Transmission Lines with Geometrical Discontinuity}

Kazuki Hiraoka, Student Member, Mitsuo Nakajima, Non-Member (Tokyo Institute of Technology)

Makoto Shiho, Non-Member (Japan Atomic Energy Research Institute)

Kazuhiko Horioka, Member (Tokyo Institute of Technology)

\begin{abstract}
Space charge electrons transport a considerable fraction of current in magnetically insulated transmission lines (MITLs). When MITL has geometrical discontinuity, the interaction between the disturbed electrons and non-linearly coupled electromagnetic field makes their behavior difficult to predict. In this paper, the power flow through those MITLs is discussed using a particle simulation code and an analytical model. The results show that the space-charge electrons tend to maintain the effective impedance of the transmission lines, by changing their distribution and boundary of the space charge flow. Although a fraction of the space charge flow shunts the gap when the discontinuity is larger than the critical value, the total current upstream the discontinuity is still preserved.
\end{abstract}

キーワード：磁気絶縁, 実効インピーダンス, 伝送線, 空間電子流

1.はじめに

伝送線によってTWクラス以上の大電力を伝送しよう とすると必然的に $\mathrm{MV} / \mathrm{cm}$ 以上の高電界が伴うが、どのよ うな材料を用いたとしても、一般に陰極表面上の局所電界 が $200 \mathrm{kV} / \mathrm{cm}$ 程度[1]を越えると陰極導体表面から電子の 電界放出が起こり、陽極に空間電子がリークしてしまう。 従って通常の伝送線ではこのような大電力を伝送するのは 不可能である。しかし、伝送線を流れるパルス電流が十分 に大きくなると、電流による自己磁場が電子の軌道を偏向 させることにより、絶縁破壊を引き起こす電場に打ち勝つ て䧔極を絶縁する(図1)。この現象を利用するのが磁気絶縁 伝送線 (Magnetically Insulated Transmission Line :

MITL )で、高エネルギー密度の電力伝送には必要不可欠な 技術である[2]。

MITLを特徵づけるのは電極間ギャップ中に存在し、電 流の一部を担う相対論的速度にまで加速された空間電荷電 子流である。MITL内部では強力な電磁場と相対論的レベ

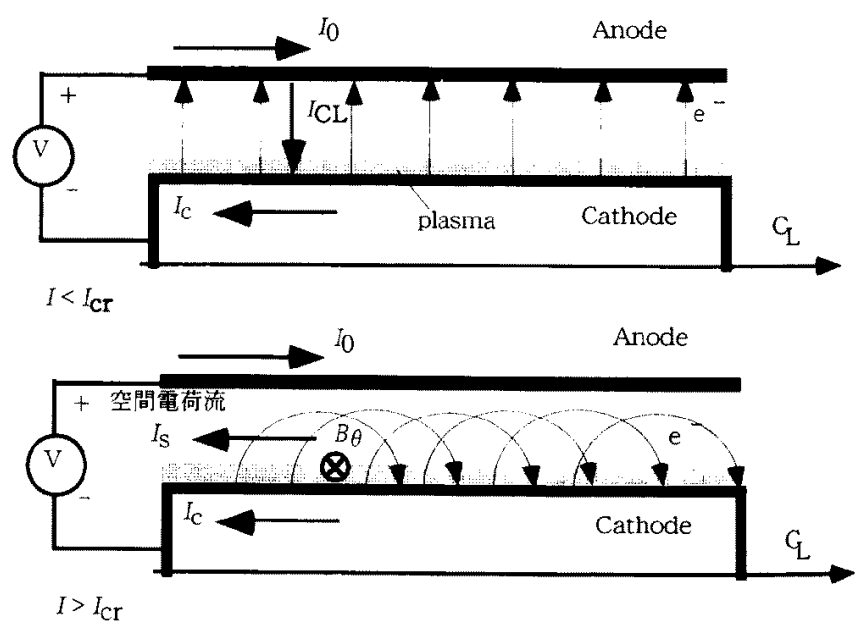

図1 磁気絶縁伝送線の概念図

Fig.1 Schematic diagram of MITL

ルにまで加速された荷電粒子とがエネルギーのやり取りを 行ないながら電力輸送が行なわれる。

相対論的に振るまう荷電粒子と電磁場を記述するエネ 
ルギー保存則は以下のように書ける[3]。

$$
\frac{\partial}{\partial t}\left(\frac{1}{2} \mu_{0} \boldsymbol{H}^{2}+\frac{1}{2} \varepsilon_{0} \boldsymbol{E}^{2}+\frac{T}{q} \rho\right)=-\operatorname{div}\left(\boldsymbol{E} \times \boldsymbol{H}+\frac{T}{q} \boldsymbol{J}\right)
$$

ここで、左辺は単位体積当たりの電力密度と荷電粒子の工 ネルギーの時間変化であり、右辺は境界から流出する電磁 エネルギーと荷電粒子の運動エネルギーを表している。ま た、 $\mu_{0} 、 \varepsilon_{0}$ はそれぞれ真架の透磁率と誘電率、Eは電 場、 $H$ は磁場、qは荷電粒子の電荷、 $\rho$ は電荷密度、Jは電 流密度、Tは電子の相対論的運動エネルギーである。これ は言い換えれば、MITL内部では線路の単位長さあたりの エネルギー $W_{\mathrm{L}}$ が、電場のエネルギー $W_{\mathrm{E}}$ ，磁場のエネルギ 一 $W_{\mathrm{H}}$ 、粒子の運動エネルギー $W_{\mathrm{KE}}$ にって

$W_{\mathrm{L}}=W_{\mathrm{E}}+W_{\mathrm{H}}+W_{\mathrm{KE}}$

というように分配されて運ばれるということを意味する。

四2の上うに伝送線路に幾何学的不均一がある場合、 空間電子流は、幾何学的不均一による電場、磁場の変化に よって擾乱を受け、電子流が変化することによりギャップ 間の電場、磁場は影響を受けると同時に電子流の挙動にフ イードバックされる。通常の伝送線路では電力が電場 $\left(W_{\mathrm{E}}\right)$ と磁場 $\left(W_{\mathrm{H}}\right)$ のみによって運ばれるため、電力の流れは線 路の形状によって一意に決まり、解析的に予測可能であ る。しかし、MITLの場合は擾乱を受けた空間電子流の ギャップ間の分布に自由度があり、場と電子が非線形に結 びついて複雑な振るまいをするため予測が困難である[4]。

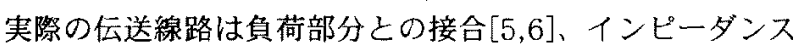
のマッチング[7-9]、測定装置の設置[10]などのためにしば しば形状を変化させることが必要となる。

このような背景のも之、荷電粒子と相互作用する電磁 エネルギーが不均一部に流入したとき、空間電子流の分布 はごのように決定されるのか解明し、不均一部の擾乱が電 力輸送に及ほす影響を明らかにすることが本研究の目的で ある。本研究ではPIC(Particle-in-Cell)シミュレーション を用いて下流で㓌極半径が小さくなるような形状のMITL について数值実験的に調べた。また解析モデルとして電流 密度分布一様モデルを提案し、このモデルによって電流の 損失が㧍こらない限界值を予測できることを示した。

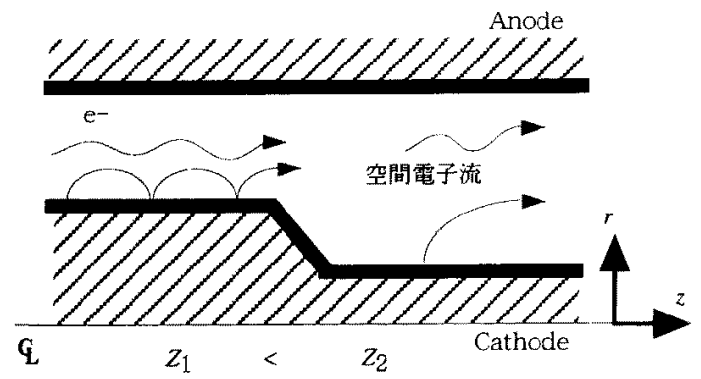

図2 磁気䋓縁伝送線に幾何学的不均一がある場合の 空間電子流の挙動

Fig. 2 Behavior of space charge electrons in MITL with geometrical discontinuity

\section{PICシミュレーション}

$<2.1>$ 計算条件断面変化を持つMITLの電力輸送特 性を調べるために、負荷の影響がない場合(自己制限モ一 ド)でのMITLの動作について粒子シミュレーションを行っ た。これは伝送線が十分長い場合、もしくは負荷のインピ ーダンスが伝送線下流部と適合している場合に相当する。 陽極(外側導体)の半径 $r_{\mathrm{a}}$ が一定で陰極(内側導体)半径 $r_{\mathrm{C}}$ が $Z$ 軸上で途中 $(\mathrm{z}=15 \mathrm{~cm})$ から小さくなるようなMITLでの電力 伝送の様子を2.5次元PICコードMAGIC[11]を用いて計算

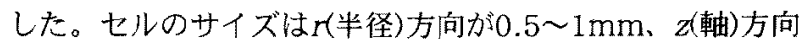
が2.5〜5mmとした。時間ステップは2〜3ps、マクロ粒子 数は50万〜200万である。

入力側境界 $(z=0)$ には空間電荷のない陽極一陰極間に 2MVの電厈がかかるような分布の電場を与えている。従っ て、入力端の幾何学的形状で決まる線路のインピーダンス( 幾何学的インピーダンス $\left.Z_{0}\right)$ に適合する電源で駆動するの と等伍である。実際には空間電荷の存在のため、実効イン ピーダンスが低下し、MITLの電極間には1.5MVの電圧が かかる。電圧パルスはt=0で入射し始め、立上り時間 $0.5 \mathrm{~ns}$ でその後は一定值を維持するとしている。最初の数 $\mathrm{cm}$ は空間電子流層が完全に形成されていないので $こ=5 \mathrm{~cm}$ 実 質的な入力端とする。出力側境界 $(z=100 \mathrm{~cm})$ では電磁波お よび電子はそのまま反射することなく計算領域から出てい く。陽極、陰極はともに完全導体とし、電子の放出は陰極 からのみとした。電子が放出される局所電場のしきい值は $0.23 \mathrm{MV} / \mathrm{cm}$ とし、一度電子が放出し始めた陰極面上のセ ルでの電場は 0 とする。これは陰極表面で局所電場がしき い值をこえるとプラズマが形成されて電場が空間電荷制限 条件になることに相当する。電子の初速度は熱速度程度 $(5$ $\left.\times 10^{6} \mathrm{~m} / \mathrm{s}\right)$ としている。

伝送線を流れる全電流 $I_{0}$ の值は陽極面内側の磁場から 計算した值を、陰極導体を流れる電流 $I_{\mathrm{C}}$ は陰極面より内側 の磁場から計算した値を用い、 $I_{0}$ と $I_{\mathrm{C}}$ の差を空間電子流 $I_{\mathrm{S}}$ と見なした。電極間の電位差 $V_{0}$ は電場を $r$ 方向に積分して 求め、伝送される電力は $P=I_{0} \times V_{0}$ の積を用いて算出し た。また線路の寒郊インピーダンスは $Z_{\mathrm{ef}}=V_{0} / I_{0}$ と定義し た。電力輸送の議論にはパルスフロントが計算領域を通過 して、MITLが十分定常に垟した $t=7.5 \mathrm{~ns} \sim 8.0 \mathrm{~ns}$ の值の平 均值を用いている。

<2.2> 損失のある場合図3に幾何学的インピーダン スが $41.6 \Omega$ (半径比2)から $138 \Omega$ (半径比10)へと階段状に大 きくなる場合の電流、電圧の典型的な波形を示す。空間電 子電流によって全電流の半分程度が運ばれているのが分か る。また通常の伝送線とは異なり、幾何学的形状の変化に よる上流への反射波が見られない。また電流值は下流で減 少しているのに対し、電極間電位差は上流と下流でほぼ同 じに保たれている。通常の伝送線では下流でインピーダン スが大きくなれば、時間の経過(この場合は1ns程度)ととも 

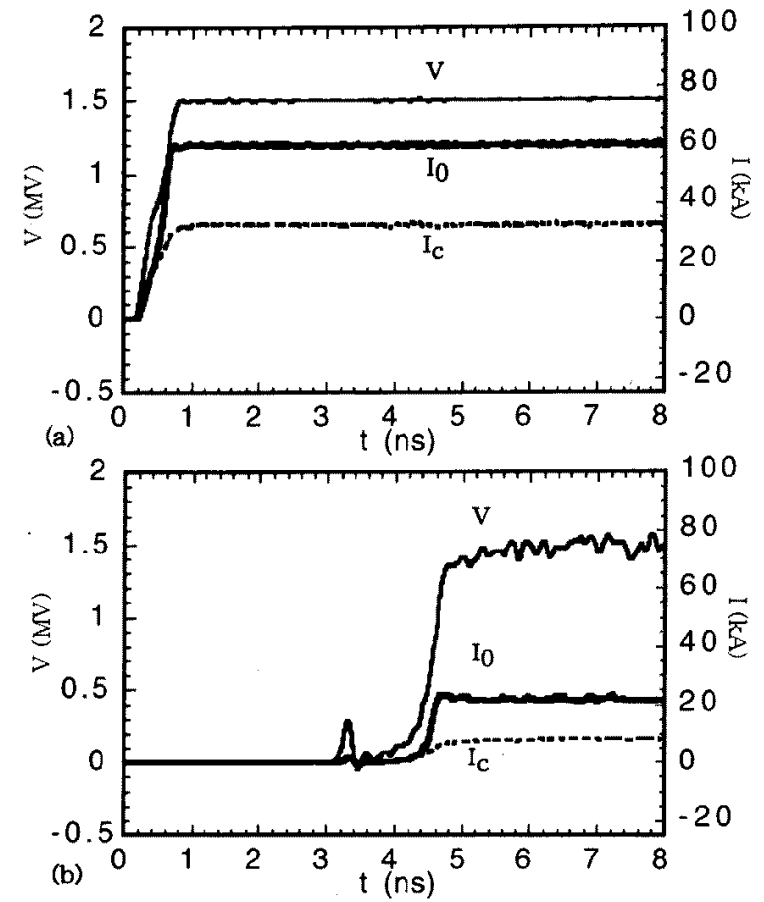

図3 上流の半径比 2 (陽極半径 $5 \mathrm{~cm}$, 陰極半径 $2.5 \mathrm{~cm}$ ), 下流 の半径比 10 (陽極半径 $5 \mathrm{~cm}$, 陰極半径 $0.5 \mathrm{~cm}$ )の場合の電流 と電圧の波形 $(\mathrm{a})$ 上流 $(z=5 \mathrm{~cm})$, (b)下流 $(z=95 \mathrm{~cm})$ Fig.3 Plots of currents and voltage of electromagnetic pulse through MITL with step discontinuity. (upstream; $r_{\mathrm{a}}=5 \mathrm{~cm}, r_{\mathrm{C}}=2.5 \mathrm{~cm}$, downstream; $r_{\mathrm{a}}=5 \mathrm{~cm}$, $\left.r_{\mathrm{C}}=0.5 \mathrm{~cm}\right)(\mathrm{a})$ at $z=5 \mathrm{~cm}$ and (b)at $z=95 \mathrm{~cm}$.

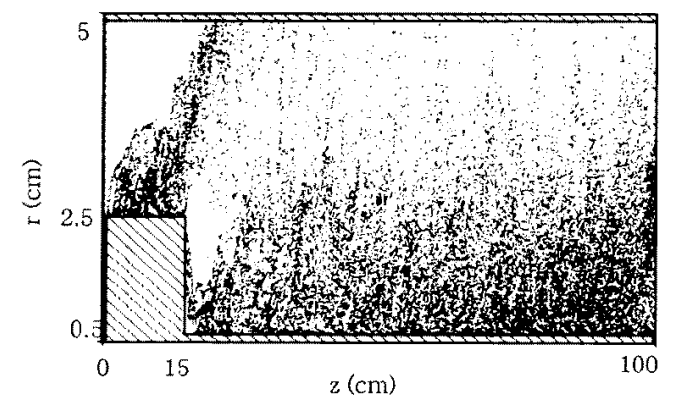

図4 上流の半径比 2 (陽極半径 $5 \mathrm{~cm}$, 陰極半径 $2.5 \mathrm{~cm}$ ), 下流の半径比 10 (陽極半径 $5 \mathrm{~cm}$, 陰極半径 $0.5 \mathrm{~cm}$ ) で ステップ状の不連続を持つMITL内の電子の分布 $(t=8 \mathrm{~ns})$

Fig. 4 Electron distribution at $t=8$ ns for the case of Fig. 3.

に幾何学的不連続部で生じた反射波が上流に達し、電位差 が大きくなり電流值は減少するはずである。

このような通常伝送線との違いは空間電子流の挙動で 説明できる。図4にパルスフロントが終端に详して十分時 間が経過した後の電子の分布を示す。上流から不連続部に 流入した電子流は擾乱を受け大部分が陽極へ流入してい る。陽極へ飛び込む電子の単位時間当たりのエネルギーを
合計すると上流と下流の電力の差とほぼ一致し、従って電 流の損失は空間電子流の陽極への流入によるものである [4]。通常の伝送線ではインピーダンスが大きくなると電位 差が増加するが、MITLでは電位差が增加しようとすれ ぱ、それによって空間電子が の場合には反射波となる分のエネルギーを受け取って陽楅 および下流に流入する。従って反射波は生じない。また不 連続部で下流と並列に電流路ができるため、上流と下流の 電位差は同じ值に維持されることが明らかになった。

<2.3> 損失のない場合上述の例で幾何学的丹ンピー ダンスの変化によって電流の大きな伝送損失があったが、 幾何学的变化がもつと小さい場合は反射波の有無や伝送損 失はどうなるであるうか。

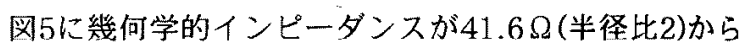
$46.6 \Omega$ (半径比 2.17 )へとわずかに大きくなる場合の電流、 電圧の典型的な波形を示す。幾何学的変化が小さい場合は 全電流値 $I_{0}$ は上流と下流で一致しており、電流の損失が全 くないことが分かる。この場合でもやはり上流への反射は 見られず、電位差も上流と下流で同じ值に維持されてい る。空間電子電流 $I_{S}\left(I_{0}-I_{C}\right)$ の全電流に対する比率は上流の $50 \%$ 程度から下流では60\%へ之増加している。

この場合の空間電子の挙動を見てみよう。電子の分布
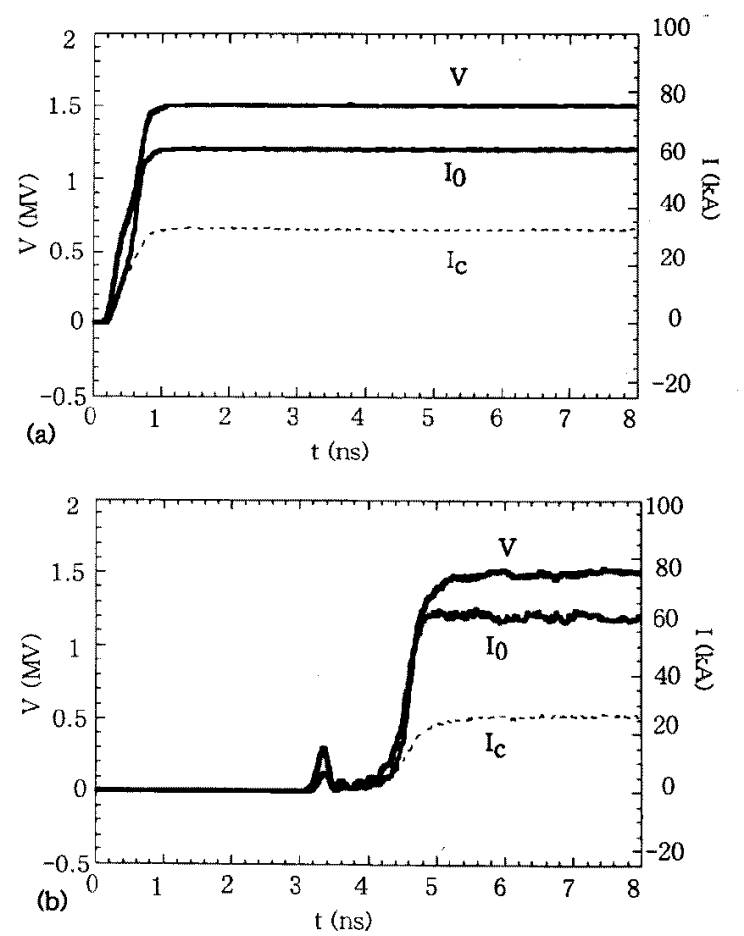

図5 上流の半径比 2 (陽極半径 $5 \mathrm{~cm}$, 陰極半径 $2.5 \mathrm{~cm}$ ), 下流の半径比 2.17 (陽極半径 $5 \mathrm{~cm}$, 陰極半径 $2.3 \mathrm{~cm}$ ) の場合 の電流と電圧の波形 $(\mathrm{a})$ 上流 $(z=5 \mathrm{~cm}),(\mathrm{b})$ 下流 $(z=95 \mathrm{~cm})$ Fig.5 Plots of currents and voltage for smaller geometrical change. (upstream; $r_{\mathrm{a}}=5 \mathrm{~cm}, r_{\mathrm{C}}=2.5 \mathrm{~cm}$, downstream; $r_{\mathrm{a}}=5 \mathrm{~cm}, r_{\mathrm{C}}=2.3 \mathrm{~cm}$ ) 

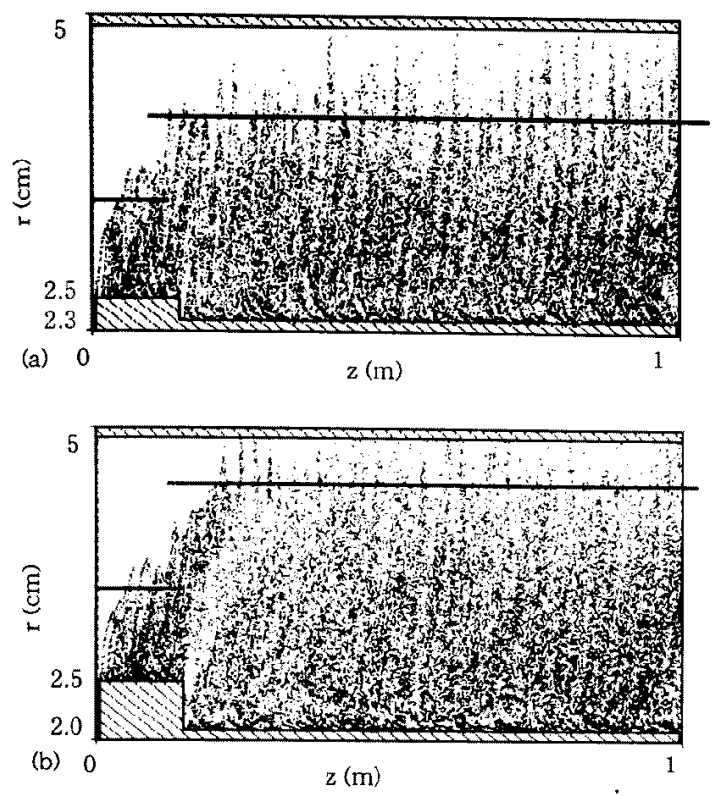

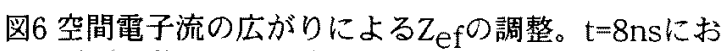
ける電子の位置 (a)上流 $Z_{0}=41.6 \Omega$ 、下流 $46.6 \Omega$ (b) 上流 $Z_{0}=41.6 \Omega$ 、下流55.0 $\Omega$

Fig. 6 Adjustment of $Z_{\text {ef }}$ by modulation of electron flow. (a) upstream $Z_{0}=41.6 \Omega$, downstream $46.6 \Omega$ (b) upstream $Z_{0}=41.6 \Omega$, downstream $55.0 \Omega$

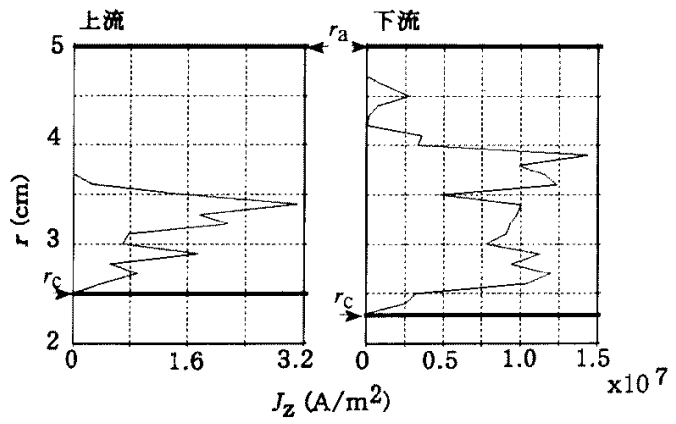

図7 図6(a)の場合の電流密度分布

Fig.7 Current density profile for the case of Fig.6(a)

を図6(a)に示す。図6(b)には下流の幾何学的インピーダン

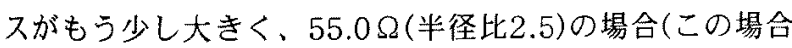
も電流損失はない)の空間電子の分布を示した。また図7に 図6(a)の場合の不連続部上流と下流での電流密度分布を示 す。下流では電流密度分布が $\mathrm{万}$ 向にほぼ一様になること、 空間電荷層の境界が陽極側に移つていることが分かる。不 連続部で陽極近くまで加速された電子は速度が大きいため より多くの電流を担うようになる。さらに不連続下流で電 子が追加放出され、空間電子流 $I_{S}$ は增加し、陰極の伝導電 流 $I_{C}$ は減少する。下流で幾何学的なインピーダンスが增加 するような不連続があると、架間電子流の割合が增えると ともに空間電荷層が陽極側まで払がることがわかる。この ような電子流の挙動によって下流の実効インピーダンスは 上流とほぼ同じ值に調整されていることが明らかになっ

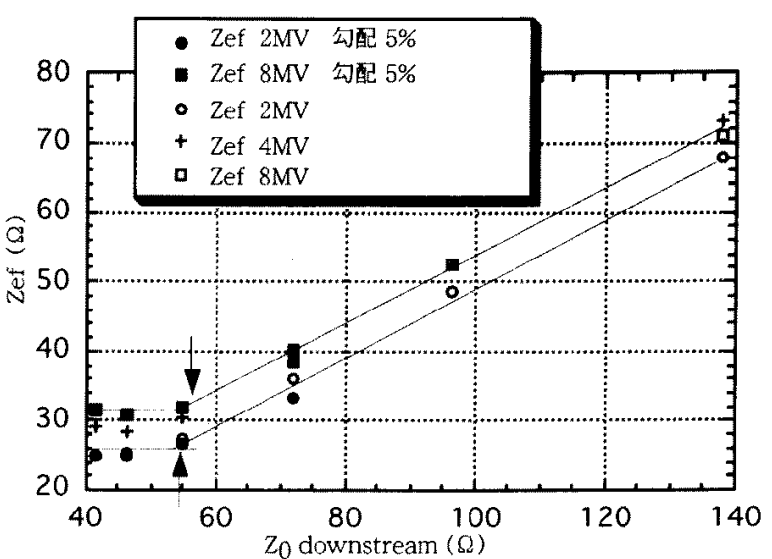

図8下流での幾何学的インピーダンスに対する実効インピ ーダンス (矢印はインピーダンスの維持限界)

Fig. 8 Effective impedance vs. geometrical impedance. (Arrows show the limit of impedance adjustment.)

た。

<2.4> 実効インピーダンスの幾何学的インピーダンス依存

性図8に下流の幾何学的インピーダンス $Z_{0}$ と実効イ ンピーダンス $Z_{\mathrm{ef}}$ の関係を示す。ここでは比較のため印加 電圧が2MV、4MV、8MVの場合と陰極半径が直角に変化 している場合、5\%の勾配の場合もプロットしている。電位 差や勾配により違いはあるが、どのパラメータの場合も同 じ傾向が見られる。下流の $Z_{0}$ がある限界值までは下流の $Z_{\mathrm{ef}}$ は一定值(上流と同じ值)であるが、それをこえると電流

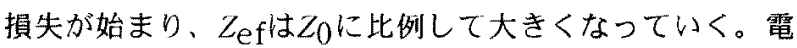
極間電位差は常に一定なので、 $Z_{\mathrm{ef}}$ の增加は即ち全電流値 の減少乙電力損失が発生することを意味する。

下流で幾何学的インピーダンスが大きくなるような不 均一があるMITLの挙動は次のように要約できる。空間電 子流は幾何学的変化に対して、「方向に拡がることにより、 可能な限りその影響を打ち消して電流值を維持する力向に 応答するが、ギャップ間一杯に拡がっても調整し切れない 場合は陽極に接触し損失となる。損失が起きた場合でも ギャップ間の電位差は維持され、上流への影響はない。

\section{3. 電流密度一様層流モデル}

以上述べたMITLの振る舞いは基本的には非線形な現象 で、その予測にはある程度数值㬰験的な方法に頼らざるを 得ないが、著者らはこのような大さな払がりを持った下流 での空間電子流を取り扱う解析モデルとして電流密度分布 一様層流モデルを提案した。このモデルは層流近似と図 9(a)に示すような一様電流密度分布を仮定してMaxwell方 程式解くことによって得られる。ここで図中の $r_{\mathrm{C}}<r<r_{\mathrm{C}}$ の領域は空間電子が存在するが、電流はほとんど流れてい ないと仮定している。

層流モデルとしてよく用いられるものとして、陰極を 

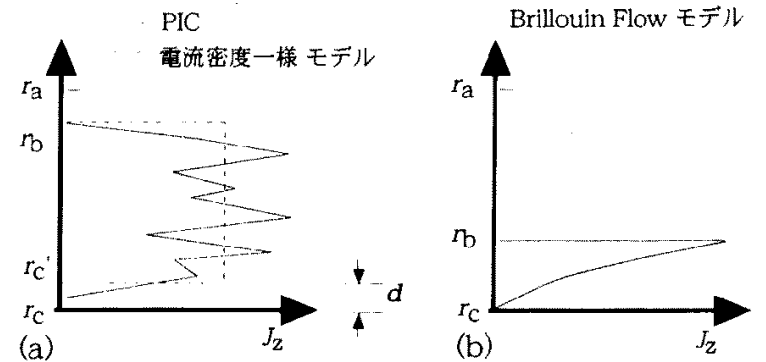

図9 数值計算によって得られた不連続部下流での典型的な 電流分布と電流密度一様モデル(a)、Brillouin Flow モデ ルの電流分布(b)の概念図

Fig.9 Schematic diagram of typical current density profile by PIC and constant current density model(a), Brillouin Flow model(b)

速度0で電子が飛び出し、正隼運動量が保存されると仮定 したMaxwell方程式の平衡解であるBrillouin Flowモデル $[2,12,13]$ がある。このモテルにより図9(b)のような電流密 度分布が解として得られる。擾乱のない上流ではPICの結 果(図7参照)と近いが、下流では電流密度分布はPICの結果 と大きく異なる。電子流が擾乱を受け運動量の分布が変化 した下流ではこの仮定は適切ではないことがわかる。従っ て不連続部下流の空間電子流に対しては電流密度分布一様 㬝流モデルを用いるのが適切であると考えられる。

この電流密度分布一様モデルを用いて、空間電子流層 のr方向の広がりによって $Z_{\mathrm{ef}}$ の值がどの程度変化するかを 検討してみよう。このモデルによる $Z_{\mathrm{ef}}$ の導出を以下に簡 単に示す。首流近似より、空間電子の運動量の変化を 0 と すると空間電子の運動方程式は

$$
\frac{\mathrm{d} p}{\mathrm{~d} t}=0=-e(E+v \times B)
$$

ここでpは電子の相対論的運動量である。空間電荷層中に 於けるMaxwell方程式は

$$
\begin{aligned}
& \nabla \cdot \boldsymbol{E}=\frac{\rho}{\varepsilon_{0}} \\
& \nabla \times B=\mu_{0} j \\
& j=\rho \boldsymbol{v}=\text { const. }
\end{aligned}
$$

と表される。Vは電子のドリフト速度であり、クは仮定によ り一定値である。また電流密度一様の仮定により磁場は

$$
B_{\theta}(r)=\frac{\mu_{0}}{2 \pi r}\left(I_{c}+\frac{r^{2}-r_{c}^{2}}{r_{b}^{2}-r_{c}^{2}} I_{s}\right)
$$

となる。式(4)〜 (7)を用いて式(4)からV、。、Bを消去し、 微分方程式を解くことにより $r$ 方向の電場 $E_{\mathrm{r}}$ を求めること ができる。 $r_{\mathrm{C}}{ }^{\prime}=r_{\mathrm{C}}$ の場合を例として示すと、空間電荷層 $\left(r_{\mathrm{C}}<r<r_{\mathrm{b}}\right)$ における $E_{\mathrm{r}}$ は $r_{\mathrm{b}} 、 r_{\mathrm{C}}$ 、および $=I_{\mathrm{C}} / I_{\mathrm{S}}$ を用いて、

$$
\begin{aligned}
E_{\mathrm{r}}(r)= & \sqrt{\frac{\mu_{0}}{2 \varepsilon_{0}}} \frac{I_{0}}{\pi\left(r_{\mathrm{b}}^{2}-r_{\mathrm{c}}^{2}\right)(1+s)} \\
& \times\left[\left\{s\left(r_{\mathrm{b}}^{2}-r_{\mathrm{c}}^{2}\right)-r_{\mathrm{c}}^{2}\right\}+\frac{1}{2} r^{2}-r_{\mathrm{c}}^{2}\left\{s\left(r_{\mathrm{b}}^{2}-r_{\mathrm{c}}^{2}\right)-\frac{r_{\mathrm{c}}^{2}}{2}\right\} \frac{1}{r^{2}}\right]^{\frac{1}{2}}
\end{aligned}
$$

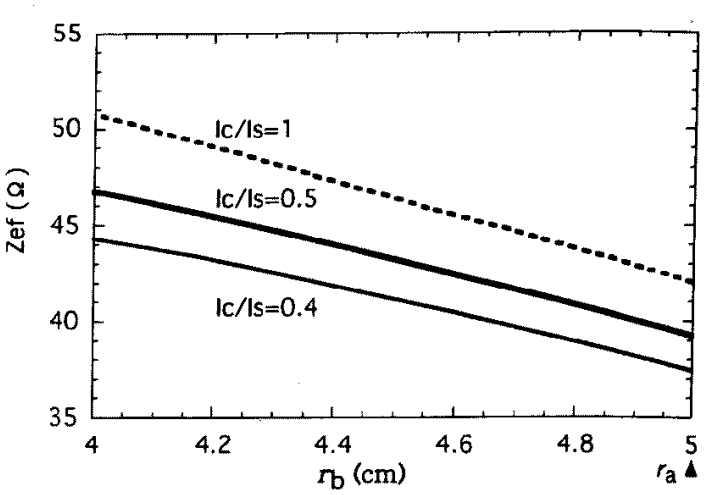

図10 空間電荷層の外縁 $\mathrm{h}_{\mathrm{b}}$ に対する $Z_{\mathrm{ef}}$ の依存性 （陽極半径 $5 \mathrm{~cm}$ 、陰極半径 $2 \mathrm{~cm}$ )

Fig. $10 Z_{\text {ef }}$ vs. boundary of space charge layer, $r_{\mathrm{b}}$ $\left(r_{\mathrm{a}}: 5 \mathrm{~cm}, r_{\mathrm{C}}: 2 \mathrm{~cm}\right)$

と表される。また、解の存在条件から、

$$
s \geq \frac{1}{\left(\frac{r_{\mathrm{a}}}{r_{\mathrm{c}}}\right)^{2}-1}
$$

という条件が必要となる。

(3)式を $r=r_{\mathrm{C}}$ から $r_{\mathrm{b}}$ まで積分すると、架間電荷層の電 位差が求められ、空間電荷層と陽極の間 $\left(r_{\mathrm{b}}<r<r_{\mathrm{a}}\right)$ の電位差 を加えることにより電極間電位差 $V_{0}$ を求めることができ る。この $V_{0}$ を全電流 $I_{0}$ で割ることにより実効インピーダン スZ $Z_{\mathrm{ef}}$

$$
\begin{aligned}
& Z_{\mathrm{ef}}=\frac{1}{4 \pi(1+s)} \sqrt{\frac{\mu_{0}}{\varepsilon_{0}}} \\
& \times\left\{\sqrt{1+2 s}\left(2 \ln \frac{r_{\mathrm{a}}}{r_{\mathrm{b}}}+1\right)+\frac{s r_{\mathrm{b}}^{2}-s r_{\mathrm{c}}^{2}-r_{\mathrm{c}}^{2}}{r_{\mathrm{b}}^{2}-r_{\mathrm{c}}^{2}} \ln \frac{1+s+\sqrt{1+2 s}}{s}\right\}
\end{aligned}
$$

上見積られる。空間電荷流が陽極まで拡がっている場合

は、 $r_{\mathrm{b}}=r_{\mathrm{a}}$ とおいて、

$$
Z_{\mathrm{uf}}=\frac{30}{1+s}\left[\sqrt{1+2 s}+\left\{s-\frac{1}{\left(\frac{\left.r_{\mathrm{a}}\right)^{2}-1}{r_{\mathrm{c}}}-1\right.}\right\} \ln \frac{1+s+\sqrt{1+2 s}}{s}\right]
$$

となる。この值が空間電子流一様モデルを用いた時のイン ピーダンスの下限となる。

図10に一様電流密度分布を仮定し、陽極半径 $5 \mathrm{~cm}$ 、陰 極半径 $2 \mathrm{~cm}$ の場合 $\left(Z_{0}=55 \Omega\right)$ の、空間電荷層の外縁 $\Gamma_{\mathrm{b}}$ に対 する $Z_{\mathrm{ef}}$ の値の変化を示す。 $I_{\mathrm{C}}$ と $I_{\mathrm{S}}$ の比を一定とした場合に はクが $1 \mathrm{~cm}$ 陽極側に拡がると $Z_{\mathrm{ef}}$ は5 $\Omega$ 程度低下する。また $I_{\mathrm{C}} / I_{\mathrm{S}}=1$ の場合と $I_{\mathrm{C}} / I_{\mathrm{S}}=0.4$ の場合でも $5 \Omega$ 程度の逗いがあ り、 $Z_{0}=55 \Omega$ に対して空間電子流の割合や電流層外縁の位 置によって $Z_{\mathrm{ef}}$ が容易に変化し得ることを示している。

\section{4. シミュレーションとの比較}

次に電流密度分布一様モデルとPICシミュレーション の計算結果の平均値から算出した $Z_{\mathrm{ef}}$ の值を比較した。困 11 に空間電子流が陽極まで拡がった場合 $\left(r_{\mathrm{b}}=r_{\mathrm{a}}\right)$ の、モデル 


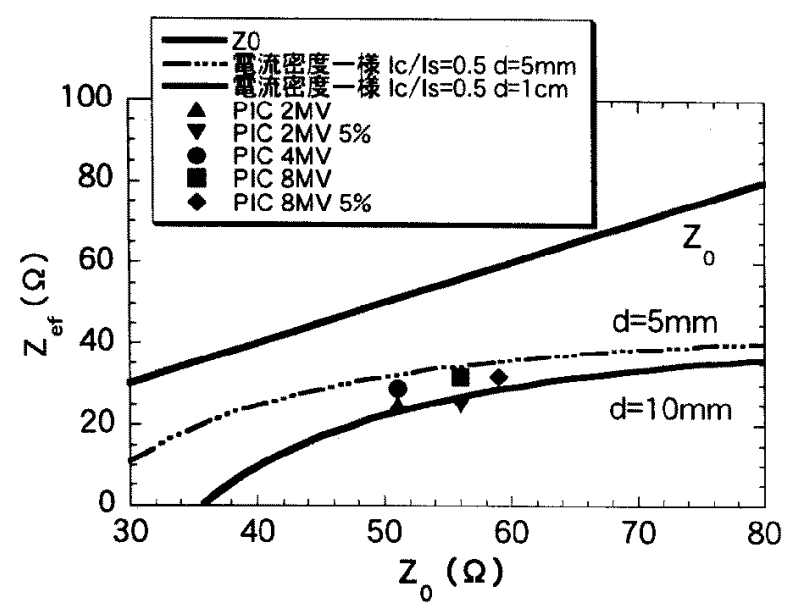

図11PICのインピーダンス維持限界との比較

Fig.11 Limit of impedance adjustment obtained by constant current density model and PIC

とPICから求めた $Z_{\mathrm{ef}}$ の維持限界(空間電子流が陽極まで拡 がったときを維持限界とする)を示す。解析モデルでは $d\left(=r_{\mathrm{C}}{ }^{\prime} r_{\mathrm{C}}\right)$ が $5 \mathrm{~mm}$ の場合と $10 \mathrm{~mm}$ 場合についてプロット した。 $Z_{\mathrm{ef}}$ の維持限界における伝導電流と空間電子流との 比 : $s=I_{\mathrm{C}} / I_{\mathrm{S}}$ の值はPICによる計算結果では0.4〜0.6(電極間 電位差が大きいほどsはささなる傾向にある)程度である ので、代表してs=0.5の場合の值をプロットした。PICの結 果と解析モデルの予測はよく一致している。

しかし上述のような議論では、sの值に任意性があるた めに実効インピーダンス $Z_{\mathrm{ef}}$ の限界がどの程度か予測しづ らい。陽極への電子流の流入が起こり始めると大きな伝送 損失になるため、空間電子流の分布変化によってどこまで

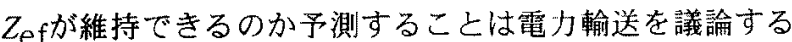
上で非常に重要である。そこでડを決定する別の条件が必 要となる。 $Z_{\mathrm{ef}}$ の維持限界を $Z_{\mathrm{ef}}$ のとり得る最小值、つまり 空間電荷層が陽極ぎりぎりまで拡がり、かつ空間電子電流

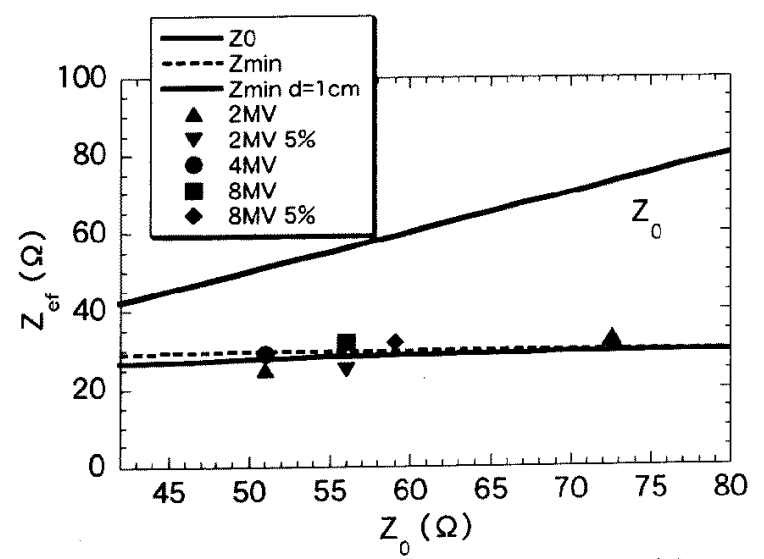

図12 電流密度一様モデルの解の存在限界 $\left(Z_{\mathrm{min}}\right)$ とPIC の $Z_{\mathrm{ef}}$ 維持の限界值

Fig. 12 Lower limit of solution for constant current density model $\left(Z_{\mathrm{min}}\right)$ and $Z_{\mathrm{ef}}$ maintainance limit obtained by PIC.
の全電流に対する割合が最大の場合とすると、後者の条件 はsが最小值をとることに相当する。sの最小值は(9)式から 与えられ、 $s=1 /\left(\left(r_{\mathrm{a}} / r_{\mathrm{C}}\right)^{2}-1\right)$ となる。この条件を(11)式に 代入すると $Z_{\mathrm{ef}}$ の最小值 $Z_{\min }$ は

$$
Z_{\text {min }}=30 \sqrt{1-\left(\frac{r_{c}}{r_{a}}\right)^{4}}
$$

となる。

図12に電流密度一様モデルの $Z_{\mathrm{ef}}$ の下限 $Z_{\mathrm{min}}$ とPICに よって得られた $Z_{\mathrm{ef}}$ の維持限界を示す。解析モデルによっ て求めた $Z_{\min }$ はが十分小さく無視できる程度の場合と、 dが10mmの場合を示した。電流密度一様を仮定したモデ ルの下限值 $Z_{\min }$ と $Z_{\mathrm{ef}}$ の維持限界はよく一致しており、空 間電子層が陽極側に拡がることによって実効インピーダン スを維持しているということを裹付けている。以上のこと から下流で $Z_{0}$ が大きくなるような場合の $Z_{\mathrm{ef}}$ の維持限界 は、電流密度一様モデルによって予測が可能であることが わかる。

また下流の幾何学的インピーダンスが大きい場合 $\left(Z_{0}>40 \Omega\right) 、 Z_{\min }$ はパラメータにかかわらずほぼ一定(30 凤程度)となることがわかる。したがって不連続に於ける空 間電于流の損失を防ぐには上流側の実効インピーダンスを

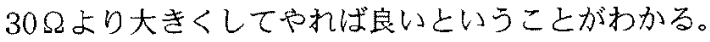

\section{5. 結論}

本論文では特に空間電子流の振るまいに着目して不連 続を持つ磁気絶縁伝送線の挙動について調べた。内容をま 上めると以下のようになる。

PICシミュレーションにより、以下のことが明らかと なつた。

1. 架間電子流は線路の不連続部(下流で幾何学的インピー ダンスが大きくなる形状)に流入すると、半径力向の分布お よび全電流に対する割合を変化させ、不連続の影響を打ち 消す方向に応答する。空問電子が幾何学的変化による影響 を吸収しきれなくなると電力輸送の損失が生じる。

2. 不均一部上流ではBrillouin Flowモデルの予测に近い電 流分布之電流密度分布を持つが、不均一部で擾乱を受けた 電子流は下流では空間電荷層の境界が変化するとともに一 様電流密度分布を持つ。

これらの数値実験結果をもとに、電流密度一様を仮定 する解析モデルを提案した。また、このモデルを用いるこ とにより、損失の起きない下流インピーダンスの限界值を 解析的に予測できることを示した。また下流の幾何学的イ ンピーダンスが $40 \Omega$ 程度より大きい場合、この限界値はほ ぼ一定(30S2程度)になることを示した。

(平成 11 年 6 月 30 日受付, 平成 11 年 10 月 18 日再受付) 


\section{文 献}

[1] R. B. Miller: An Introduction to the Physics of Intense Charged Particle Beams, (Plenum Press, New York, 1982)

[2] M. S. Di Capua: IEEE TRANSACTIONS ON PLASMA SCIENCE, PS-11 No.3, p.205-215 (1983)

[3] M. Y. Wang: Appl. Phys. Lett. 33(4), p.284 (1978)

[4] 平岡一毅, 中島充夫, 堀岡一彦, 志甫諒: プラズマ・核 融合学会誌 Vol.75-5 CD, p.57-74 (1999)

[5] D. D. Ryutov and R. N. Sudan: Proc. Beam's 94, p.144-149 (1994)

[6] K. Horioka, K. Hiraoka, M. Nakajima and T. Aoki: NIFS-PROC-23 , p.118 (1994)

[7] P. Hoppe, W. Bauer, et al.: Proceedings of 12th International Conference of High Power Particle Beams (to be published) (1998)

[8] S. E. Rosenthal: IEEE Trans. Plasma Sci., 19 No.5 p. $822-830$ (1991)

[9] M. G. Mazarakis et. al: Appl. Phys. Lett., 70 No.7 p.832-834 (1997)

[10] J. P. VanDevender: Journal of Applied Physics, 50 No.6 p.3928-3934 (1979)

[11] B. Goplen, L. Ludeking, D. Smith and G. Warren: Computer Physics Communications, 87 Nos. $1 \& 2$ p.54-86 (1995)

[12] John M. Creedon: Journal of Applied Physics, 46 No.7 p.2946-2955 (1975)

[13] M. Y. Wang: Appl. Phys. Lett. 33(4), p.284 (1978)

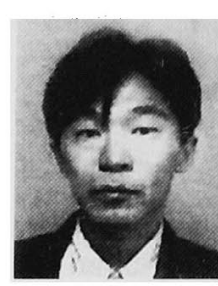

（学生員） 1969年4月17日生まれ。1994 年3月名古屋大学工学部電気電子電子情報 工学科卒業。1996年3月東京工業大学大 学院総合理工学研究科エネルギー科学専 攻修士課程修了。現在同大学大学院創造 エネルギー専攻博士課程在学。日本物理 学会会員。

中島 充夫 (非会員) 1960年11月8日生まれ。85年

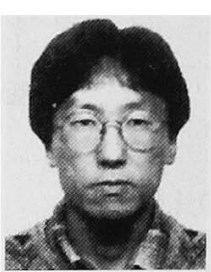
東工大物理学科卒業、 87 年同大学院原子 核工学専攻修士課程修了。東大原子炉工 学研究施設技官、東工大総合理工学研究 科技官を経て同助手、現在に至る。日本 原子力学会、日本物理学会会員。プラズ マ、原子核の研究に従事

志甫 諒 (非会員) 1946年10月18日生まれ。69

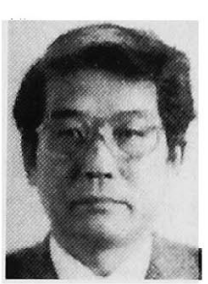
年東京大学基礎科学科卒業、75年同理学 系大学院博士課程修了。日本原子力研究 所核融合工学部次長。東京工業大学客員 教授。理学博士。日本物理学会会員。

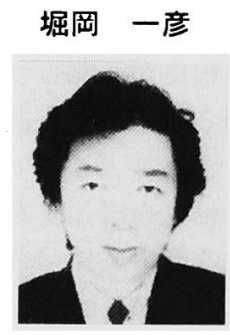

（正員）1951年10月5日生まれ。1980 年大阪大学大学院基礎工学研究科物理系 専攻博士課程修了。東京工業大学大学院 総合理工学研究科助手、助教授を経て現 在創造エネルギー専攻教授。工学博士。 日本物理学会、原子力学会、プラズマ・ 核融合学会、IEEE会員。 